\title{
The Effect of Voice Record (Murottal) of Surah Ar-Rad Verses 1-28 with Video on Elderly Anxiety Level in RW 02 Batursari Village in Covid-19 Times
}

\author{
Zulfatul Asfiyah ${ }^{1}$, Suci Ratna Estria ${ }^{2}$
}

${ }^{1}$ Student of Nursing Department, Faculty of Health Sciences, Universitas Muhammadiyah Purwokerto, Indonesia ${ }^{2}$ Lecturer of Nursing Department, Faculty of Health Sciences Universitas Muhammadiyah Purwokerto, Indonesia

\begin{tabular}{l} 
ARTICLE INFO \\
\hline Article history: \\
DOI: \\
10.30595/pshms.v2i.228 \\
Submitted: \\
December 6, 2021 \\
Accepted: \\
January 21, 2022 \\
Published: \\
January 26, 2022
\end{tabular}

\section{Keywords:}

Murottal; Anxiety; Elderly; Covid-19

\begin{abstract}
World Health Organization declared covid-19 as the sixth public health emergency that required global attention. The Covid-19 pandemic caused the risk of complications which was higher in some vulnerable populations including the elderly. Moreover, Covid-19 prevention such as self-isolation and quarantine affected community activities as well as causing psychosocial problems, one of which was anxiety. Some anxiety treatments could be conducted using distraction techniques, deep breathing, and music therapy including murottal Al Qur'an. To figure out the effect of the medium of murottal of Surah Ar-Rad verses 1-28 with video as the media on the elderly anxiety level in rw 02 Batursari village in Covid-19 times. The study used a pre-experimental design with one group pretest and posttest design. Measurement of research variables was carried out before and after giving the medium of the video to the elderly who experienced anxiety. The samples were 41 respondents who were selected using the purposive sampling technique. The results showed that the average age of the respondents was 64 years, with an average value of anxiety level before the medium of 10.14 and after the medium, the average value of the respondent's anxiety level decreased to 3.65 or decreased by 6.49. Based on the Mann-Whitney test, the results obtained a $Z$ value of -7.897 and a significance value of 0.001 ( $p$ 0.05) with an effect size of 1.23. Therefore, there was the effect of the medium of murottal of surah Ar-Rad verses 1-28 with video on the elderly anxiety level in RW 02 Batursari village during in Covid-19 times. There is an effect of the medium of murottal of surah Ar-Rad verses 1-28 with video on the elderly anxiety level in rw 02 Batursari village during in Covid-19 times.
\end{abstract}

This work is licensed under a Creative Commons Attribution 4.0 International License.

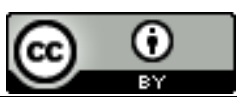

Corresponding Author:

Suci Ratna Estria,

Department of Health, Muhammadiyah University of Purwokerto,

Soepardjo Rustam Street KM. 7, Banyumas, Indonesia

Email: estriasuci@yahoo.co.id

\section{INTRODUCTION}

The The novel coronavirus 2019 (COVID-19) was first recognized on December 31, 2019, reported in Wuhan, Hubei Province, China. On January 30, 2020, WHO declared COVID-19 a health emergency. Public sixty which need attention world [1]. By global reported 90,870 confirmed cases of Covid-19 in 72 countries, with 3,112 deaths as of the $3^{\text {rd }}$ March 2020, including Indonesia [2]. According to Ministry of Health Republic Indonesia has 41,431 confirmed cases, 2,339 deaths with a CFR of 5.5\%, with an average daily increase of 1,000-1,100 cases to 1,331 cases [3]. Risk of complications From COVID-19 is higher in some vulnerable populations including the elderly, children who are suffer from weakness, or who have some chronic conditions. Death increases with with increasing age, the mortality rate among people aged 80 or over is $15 \%$ higher risk [4]. The elderly (elderly) group has physical and psychological weakness in the COVID-19 pandemic. mentioned that the majority of cases were patients aged 30 to 79 years (87\%), 1\% 
aged 9 years or younger, $1 \%$ aged 10 to 19 years, and 3\% aged 80 years [5] or older.According to the data and information center, Ministry of Health of the Republic of Indonesia , from the results of population data for the 2015-2019 health development program targets, the number of elderly people is the 6th highest with a total of 25,901,989 [6]. Covid-19 prevention measures such as self-isolation and quarantine affect people's activities as well as livelihoods, this causes problems psychosocial one of which is anxiety [7]. This statement is supported by a recent survey by the Indian Psychiatric Society showing that in India there has been a $20 \%$ increase in mental problems that have occurred since the corona virus outbreak [8]. The explanation above is also reinforced which states: explained that symptoms of anxiety disorders and depressive disorders increased rapidly in the United States during April - June 2020, compared to the same period in 2019. [9]

Anxiety if left untreated will affect health status elderly both physically and mentally, so that it will have an impact on the activities of the elderly's daily activities [10]. Handling of anxiety, can be done pharmacologically and non-pharmacologically. If by pharmacology can use drugs. Non-pharmacologically, distraction techniques, health education, family support, deep breathing, muscle relaxation can be done, music therapy including Al-Qur'an murotal, meditation, and hypnotherapy [11]. One type of music that is recommended is spiritual or murottal music. Murottal is the reading of verses of the Qur'an according to Islamic teachings which focuses on two things, namely the correctness of reading (tajwid) and the rhythm of reading the Qur'an. Listening to the verses of the Qur'an or what is commonly called murottal can provide peace for the believer [12].

Murottal therapy works on the brain, where when a stimulus is given murottal therapy, the brain will produce a decrease cortisol so that it can provide feedback in the form of feelings of relaxation and comfort. Moment listening to the holy verses of the Qur'an a Muslim in general can feel physiological changes in the form of a decrease in depression [13]. Murottal intervention can be given with a variety of media, one of which is one is with video media. Stated that video media is capable of displaying message elements clearly with simultaneous sound and displaying objects, places, and events in an attractive moving image format [14]. So based on the explanation and reference above, the researchers to interested examine and knowing is there any the effect of the intervention of murottal Al-Qur'an surah Ar-Rad verses 1-28 with video media on the level of anxiety in the elderly in RW 02 Batursari village, Sirampog district Brebes Regency during the Covid-19 pandemic as it is today.

\section{RESEARCH METHOD}

This study used a pre experimental design with one group pretest and posttest design. Measurement of research variables This study was conducted before and after the murottal video intervention was given to the level of anxiety in the elderly..

\section{RESULT AND DISCUSSIONS 3.1 Characteristic of Respondents}

Tabel 1. Frequency distribution, percentage of characteristics respondents in the elderly group giving intervention $(n=41)$.

\begin{tabular}{lcc}
\hline Characteristics of Respondents & Frequency & Percentage \\
\hline Age & 4 & \\
Middle age & 36 & $9.75 \%$ \\
Elderly & 1 & $87.80 \%$ \\
Old & 0 & $2.43 \%$ \\
Very Old & & $0 \%$ \\
Gender & 22 & \\
Male & 19 & $53.65 \%$ \\
$\quad$ Woman & & $46.34 \%$ \\
Education & 29 & \\
No School & 9 & $70.73 \%$ \\
Primary School & 0 & $21.95 \%$ \\
$\quad$ Junior High School & 3 & $0 \%$ \\
Senior High School & & $7.31 \%$ \\
Work & 13 & $31.70 \%$ \\
$\quad$ No work & 16 & $39.02 \%$ \\
Farmer & 9 & $21.95 \%$ \\
$\quad$ Laborer & &
\end{tabular}

Proceeding homepage: https://conferenceproceedings.ump.ac.id/index.php/pshms/issue/view/10 


\begin{tabular}{ccc} 
Retired & 3 & $7.31 \%$ \\
\hline Total & 41 & $100 \%$ \\
\hline
\end{tabular}

Based on table 1 above, Explain characteristics of research respondents consisting of age, education level, gender and job status of respondents study.

\subsection{Differences in Anxiety Scores Before and After Intervention}

Table 2. Distribution of the difference in anxiety scores before and after the intervention murottal

\begin{tabular}{lccccc}
\hline Variable & Anxiety & Mean Range & $\mathbf{Z}$ & $\mathbf{P}$ & $\mathbf{R}$ \\
\hline Before \pm SD & $10,14 \pm 0,963$ & 62,00 & -7.897 & 0,001 & 1,23 \\
After \pm SD & $3,65 \pm 0,911$ & 21,00 & & & \\
\hline
\end{tabular}

Table 2 shows the difference in the average anxiety scores after and before administration intervention in the elderly group and the magnitude of the results of the effectiveness of the intervention (effectiveness value $=\mathrm{R}$ ).

\subsection{The effect of voice record (murottal) of surah ar - rad verses 1-28 with video on elderly anxiety level in rw 02 batursari village in covid-19 times}

Table 3. The effect of the intervention of murottal surah ar-rad verses 1-28 with video media on the anxiety level of the elderly in rw 02 Batursari village during Covid-19.

\begin{tabular}{ccc|c|c}
\hline Variable & Before \pm SD & After \pm SD & $\Delta$ & P \\
\hline Anxiety & $10,14 \pm 0,963$ & $3,65 \pm 0,911$ & 6,49 & 0,001 \\
\hline
\end{tabular}

Table 3 explain results analysis of statistical test data on the effect of the murottal intervention of Surah Arrad verses 1-28 with video media on the level of anxiety of the elderly in RW 02 Batursari village during Covid-19

\subsection{Characteristic Of Responden}

According to the results of research that has been carried out by researchers, it shows that the average age of the research respondents is elderly (elderly) or at the age range of 60-74 years with a percentage of $87.80 \%$. This is also in line with the severity of anxiety levels will depend on the age of the individual, because age affects the way individuals evaluate conditions that cause anxiety [15]. The statement in line with the results of [16] entitled "Factors Associated with Anxiety Levels in Preoperative Patients at RSMitra Husada Pringsewu" which explains that the results of the analysis of the relationship between age and anxiety levels are $9(30 \%)$ age adults and only 1 (3.6\%) in adolescence. Teen Age with Anxiety was 16 $(57.1 \%)$ and $13(43 \%)$ in adulthood, moderate level of anxiety was $11(39.3 \%)$ in adolescence and only 7 $(23.3 \%)$ in adulthood. The level of anxiety was only found in adult respondents, namely $1(3.3 \%)$. The result of p-value $0.036<0.05$ which means that there is significant relationship between age and level of anxiety. Then for the results of the education level of the respondents, most of them are not in school, namely with a percentage level of $70.73 \%$. Based on the results of [17] entitled "The Relationship between Education Level, Income and Family Support with Anxiety in Menopausal Women in Jobohan Village, Bokoharjo, Sleman mention that of research conducted respondents, most of the respondents have low education as many as 68 respondents $(71.6 \%)$. From the results of the data analysis, it was obtained a value of $0.001<(0.05)$ so it can be concluded that there is a significant relationship between education and anxiety in menopausal women in Dusun Jobohan, Bokoharjo, Sleman 2016. The higher a person's education level, the easier it is to accept the concept of healthy living independently, creatively and sustainable. Person's level of education is influential in responding to something that comes, both from within and from outside. People who have higher education will give a more rational response compared to people who are less educated or those who are not educated at all, because the level of higher education which will broaden the views and scope of individuals and make it easier for respondents to accept information about health, so as to reduce anxiety levels [18].

Then for the gender of the research respondents, female more that is equal to $53.65 \%$ compared to men by 46, 34\% [19]. This is in line with the explaining that men are more active and explorative, while women are more sensitive than men. so a girl have a higher or predominant level of anxiety than men [20]. This is in line with the results research from Kurt,. deveci \& Oguzoricul which discusses "Levels of anxiety and depression related to covid-19 among physicians: an online cross-sectional study from Turkey" which explained that the level female physicians' anxiety and depression were significantly higher than that of male 
physicians. In addition, out of a total of 264 doctors who became respondents, the dominant average was a doctor women by $51.9 \%$ compared to a man at $48.1 \%$ [21]. The research also strengthened the results research from Mohammadpour,. Et all which discusses "Anxiety, self-compassion, gender differences and covid-19: predicting self-care behaviors and fear of covid19 based on anxiety and self-compassion with an emphasis on gender differences" stated that the research conducted on 403 people with average age $31.08 \pm$ 9.75 years. Of them, $120(29.8 \%)$ were male, and $283(70.2 \%)$ were female, it can explain that the average characteristics of the respondent is a woman [22].

And for the average respondent's occupation, the majority are farmers with a percentage of by $39.02 \%$ and not working with a percentage of $31.70 \%$. Based on the results of "The relationship between education level and work status with anxiety in third trimester pregnant women" stated that the work of the research respondents the majority are 16 respondents do not work (53.3). it is known that the $\mathrm{p}$ value is 0.01 where the $\mathrm{p}$ value is $<0.05$ so it can be stated that Ho is rejected and $\mathrm{Ha}$ is accepted, so it is stated that there is a relationship between work status and anxiety in third trimester pregnant women at the Puskesmas Umbulharjo [23]. This is in line with the opinion of said that work is one of the determinants of economic status somebody. From one's work one will get income and income will affect anxiety because there is a relationship between economic status and worry [24].

\subsection{Differences in Anxiety Scores Before and After}

Based on table 4.2 it is known that the average value of the level respondent's anxiety is 10.14 with SD of 0.963 and after the intervention the average value of the respondent's anxiety level to be 3.65 with SD 0.911. In this study, the mean range before the intervention was 62.00 and after the intervention was 21.00, then for the $\mathrm{Z}$ value of -7.897 and the $\mathrm{P}$ value $=<(0.001)$. anxiety is one of the cognitive disorders experienced by the elderly, because according to old age is often seen as a period of decline, a period in which the elderly feel declines that cause many changes in their lives himself physically, psychologically, social and spiritual, it is also what causes the emergence of worry [25,26].

The Covid-19 epidemic has caused serious threats to physical health and human life. It also triggers various psychological problems, such as panic disorder, anxiety and depression. Some of the vulnerable groups in the Covid-19 pandemic, one of which is the elderly [27]. According to Stuard in Arifiati \& Wahyuni's research (2019) states that the anxiety experienced by the elderly tends to be unclear feelings of concern, which are related to feelings of uncertainty and helplessness against a condition, such as the conditions during the COVID-19 pandemic [28]. Anxiety overall more than tall normally and the general population during Covid-19. Between SAS scores and confirmed cases in every city except Wuhan or every province except Hubei province. Any major epidemic outbreak will always have a negative effect on individuals and society. A study of the psychological state of 600 people during the Covid-19 outbreak showed that their SAS score was 36.92 ( $\mathrm{SD}=7.33$ ) and 6.33\% had anxiety [29]. During the past year, the Covid-19 pandemic has affected many people's life activities. The pandemic Covid-19 has changed all aspects of people's lives. The elderly are no exception. Psychosocial effects tend to last longer than the pandemic itself. Isolation during a number of moon raises saturation, anxiety, even insomnia [30]. Coupled with information about the increasing number of COVID-19 cases, which continues to increase, so that it has a bad impact on mental health everyone, especially the elderly who are more prone to experiencing anxiety, such as setbacks physical experience. [31]

Respondent's anxiety research before doing the provision of murottal intervention was still in moderate and severe levels of anxiety but after the murottal intervention, respondent's anxiety level decreased so that anxiety levels decrease, to mild anxiety.According to previousexplained that anxiety management, can performed pharmacologically and non pharmacologically. If by pharmacology can use drugs. Nonpharmacologically, distraction techniques, health education, family support, deep breathing, muscle relaxation, and music therapy can be done, including murotal Al-Qur'an [32].

\subsection{The effect of voice record (murottal) of surah ar - rad verses 1-28 with video on elderly anxiety level in rw 02 batursari village in covid-19 times.}

The results showed that the average value of the level respondent's anxiety before giving an intervention of 10.14 with a standard deviation of 0.9633 and after giving the intervention the average value of the respondent's anxiety level decreased to be 3.65 with a standard deviation of 0.911 or the average value of the anxiety level experienced a decrease of 6.49. Results of bivariate analysis with using the MannWhitney test, the results obtained are the $\mathrm{Z}$ value of $-7,897$ and a significance value of $0.001(\mathrm{P}<0.05)$. The results of this statistical test can be stated that there is an effect of the murottal intervention of Surah Ar-Rad verses 1-28 with video media on the level of anxiety of the elderly in Batursari village during Covid-19. The results of this study are also in line with the research "The effect of murottal Al-Quran therapy on stress in 
the elderly". Research analysis using the Wilcoxon Signed Rank Test. Research result showed that before murottal al-Qur'an therapy was carried out, many experienced severe stress ( 26 elderly), moderate stress (14 elderly), and mild stress (0), after murottal al-Qur'an therapy was carried out, stress in the elderly decreased. become moderately stressed (40 elderly), stressed (severe) 0), and mild stress (0) so that in the hypothesis test using the Wilcoxon Signed Rank Test, significant results were obtained, namely p value $=0.000$, which means $\mathrm{p}$ value $<0.05$. Then $\mathrm{HI}$ is accepted [33].

Conclusion from research This explains that therapy murottal Al-Qur'an could reduce stress on elderly. According to explain that gift audio therapy with murottal Al-Qur'An is alternative new as therapy relaxation to lower anxiety, emotional instability, and sleep disturbances. Al-Quran murottal therapy can generate a delta wave in the frontal lobe as an intellectual center and emotional control, and also includes the ability to communication and social interaction, as well as a central lobe that functions as a control center for movement. Delta waves are brain waves that have a large amplitude and low frequency, which is below $4 \mathrm{~Hz}$. The brain produces these waves when a person is in a deep sleep without a dream. The body will also carry out a self-healing process, repair tissue damage and actively produce new cells while sleeping [34]. Explanation thein line with the results of "influence spiritual treatment with murottal against stress anxiety and depression in cervical cancer patients undergoing chemotherapy" which showed that the results of the paired t-test of stress, anxiety, and depression in the group treatment is $p=0.000$ which means that in general there are effect of murottal intervention to stress reduction, anxiety, and depression. The results showed that in the Anova test $\mathrm{p}=0.015$ ( $\mathrm{p}<0.05$ ), it was stated that there were differences in stress, anxiety, and depression between the treatment group and the control group [35].

Based on research "Murottal therapy affects on stress aspects in the elderly at Bpstw Yogyakarta Budi Luhur Unit Kasongan Bantul" stated that the results of statistical tests using the Wilcoxon test obtained a p-value of 0.000 for total stress, physical and behavioral aspects, because the p-value was less than 0.05 means that there is a significant decrease in stress scores in respondents who have been given murottal therapy [36]. States that from the psychotherapeutic element, religious therapy or murottal therapy is as important as psychiatry, that is, both contain spiritual power spiritual values that can increase the individual's self-confidence and optimism. Psychotherapy maybe work better compared to drugs because they seek to correct the cause anxiety is not a symptom albeit in the short term [37]. Based on study on "Comparison of the effect of instrumental music and holy Quran recitation on the anxiety of patients with acute coronary syndrome: semi-experimental study" showed that the level of anxiety decreased from $43.1 \pm 6.15$ to $38.5 \pm$ 3.82 in the study group $(\mathrm{P}<0.001)$ and from $44.2 \pm 1.21$ to $39.1 \pm 4.17$ in the instrumental music group $(\mathrm{P}=$ $0.035)$, and from $46.3 \pm 3.84$ to $44.7 \pm 6.21$ in the control group $(\mathrm{P}<0.001)$. There was no significant difference between the three groups however, the average score of anxiety levels showed a significant difference, these results indicate that listening to the recitation of the Qur'an has a greater effect than listening to music instrumental in reduce worry patient $(\mathrm{P}=0.02)$ [38].

The research above is also strengthened by the results of "Holy quran recitation of surah Al-Mulk and Al-Hasyr on decreasing anxiety in medical students" stated that there was an effect of reading the holy verses of the Qur'an Surah Al-Mulk and Al-Hasyr on anxiety $(p=0.000)$. There is a difference in the average value of anxiety before the intervention of 11.49 with an SD of 9,324 after the intervention was 4,93 with an SD of 6,910 [39]. So from the results of previous studies and the opinion above, it can be stated that there is an effect of the murottal intervention of Surah Ar-Rad verses 1-28 with video media on the level of anxiety elderly in Rw 02 Batursari moment Covid-19 Village

\section{CONSLUSION}

The average age of the research respondents was elderly (elderly) or in the age range of 60-74 years with a percentage of $87.80 \%$. The elderly who became respondents in this study were mostly female with a total of 22 elderly (53.65\%), while 19 elderly men (46.34\%). The education level of most of them are not in school with 29 elderly $(70.73 \%)$ working as farmers with a percentage of $39.02 \%$ and not working with a percentage of $31.70 \%$. 28 with video media on anxiety in Batursari village during Covid-19 with a significancy value of $0.001(\mathrm{P}<0.05)$

\section{Acknowledgements}

Thank you to Allah SWT who has made all my afairs easy up to this moment, and thank you very much to my parent and my family who always encourage me in any condition. 


\section{REFERENCES}

[1] World Health Organization. (2020). Coronavirus disease (COVID19) pandemic. Retrieved October 05, 2020. From https://www.who.int/emergencies/di seases/ new corona virus 2019

[2] Morfi,.(2020). Kajian Terkini Corona Virus Diseas 2019 (Covid-19). Jurnal Ilmu Kesehatan Indonesia- Vol. 1 No. 1.

[3] Indonesian Ministry of Health. Guidelines for the Prevention and Control of Coronavirus Disease (COVID-19). Jakarta: Indonesian Ministry of Health; 2020. p. 115

[4] Pradana, Casman \& Nuraini 2020. The effect of the Social Distancing policy on the Covid-19 outbreak on vulnerable groups in Indonesia. Indonesian Journal of Health Policy (JKKI) Vol 9, No 2

[5] Wu \& McGoogan, (2020). Characteristics of and Important Lessons From the Coronavirus Disease 2019 (COVID-19) Outbreak in China Summary of a Report of 72314 Cases From the Chinese Center for Disease Control and Prevention. American Medical Association. P-1239

[6] Indonesian Ministry of Health. Guidelines for the Prevention and Control of Coronavirus Disease (COVID-19). Jakarta: Indonesian Ministry of Health; 2020. p. 115

[7] World Health Organization. (2020). Coronavirus disease (COVID19) pandemic. Retrieved October 05, 2020. From https://www.who.int/emergencies/di seases/ new corona virus 2019 World Health Organization. (2020). Coronavirus disease (COVID19) pandemic. Retrieved October 05, 2020. From https://www.who.int/emergencies/di seases/ new corona virus 2019

[8] Loiwal. (2020). 20\% increase in patients with mental health disorders since the coronavirus outbreak: a survey. Retrieved November 11, 2020. From https://www.indiatoday.in/india/stor y/ 20per-cent-increase-in-patientswith-mentalillness-since-coronavirus-outbreak-surve

[9] Czeisler,.et all. (2020). Substance Use_mental, Health, and Self-Idea During_kill COVID-19 Pandemic — United States, June 24-30 2020. US Department of Health and Human Services.

[10] Uswatun \& Khairani. (2016). Level Anxiety in the Elderly Yang Experiencing Chronic Illness In Banda A ceh. Nursing Science Gerontik Faculty of Nursing Syiah Kuala University, Banda Aceh p.37

[11] Setyaningsih (2020). Murottal Al-Mulk Therapy in Reducing Maternal Anxiety with Pre-eclampsia. Journal of Midwifery Vol 6, No 3. Malahayati University

[12] Babamohamadi ,. Sotodehasl \& Koenig (2017) Pengaruh Alquran pada Gejala Depresi pada Pasien Hemodialisis: Uji Klinis Acak. J Relig Health. Retrieved Oktober 19,2020. From https://doi.org/10.1007/s10943-016-02810

[13] Siswantinah. (2011). The Effect Of Murotal Therapy On Anxiety Patients With Chronic Renal Failure Who Underwen Hemodialysis

[14] Pribadi,. (2017). Inner technology Learning. Jakarta: Kencana.

[15] Anam., (2017). Psychoreligious Influence Care : Listening to Murottal Al-Qur'an with Nahawand's Rhythm To Decrease Level Worry to the Elderly at UPTD Griya Wredha Jambangan Surabaya City.

[16] Vellyana,. Lestari \& Rahmawati (2017) Factors Associated with Anxiety Levels in Preoperative Patients At Mitra Husada.

[17] Setiyani \& Ayu (2019). Connection Level Education, Income And Family Support With Anxiety on Menopausal Women in Jobohan Village, Bokoharjo, Sleman 2016. Journal of Medika Respati Vol. 14 No. 2

[18] Yuniati,. (2020). Influence Therapy Progressive Muscle Relaxation Against Anxiety Levels in Elderly At Posyandu Elderly Rt 03 Rw 04 Village Tawangsari, Mojosongo Village, Surakarta. Kusuma Husada University of Surakarta

[19] Hamidiyanti \& Pratiwi (2019). Effect of Listening to the Quran on Anxiety Level in Primipara. health, Spirituality and Medical Ethics ;6(1):52-56._http://dx.doi.org/10.29252/jhsme.6.1. 52.

[20] Anam., (2017). Psychoreligious Influence Care : Listening to Murottal Al-Qur'an with Nahawand's Rhythm To Decrease Level Worry to the Elderly at UPTD Griya Wredha Jambangan Surabaya City

[21] Kurt,. Deveci \& Oguzoricul (2020) Levels of anxiety and depression related to COVID-19 among physicians: An online cross-sectional study from Turkey. Annals of Clinical and Analytical Medicine

[22] Mohammadpour,. Et all (2020) Anxiety, Self-Compassion, Gender Differences and COVID-19: 
Predicting Self-Care Behaviors and Fear of COVID-19 Based on Anxiety and Self-Compassion with an Emphasis on Gender Differences. Iran J Psychiatry ; 15:3:213-219.

[23] Suyani (2020). Level Relationship Education And Employment Status With Anxiety In Third Trimester Pregnant Women. Health Journal Public STICK Scholar Main Holy

[24] Agustine,. Handayani \& Nurjanah,. (2019). Effects of reading dhikr Asmaul Husna Ya Rahman and Ya Rahim against changes in the level of anxiety in the elderly. Journal of Physics: Conference Series

[25] Yuniati,. (2020). Influence Therapy Progressive Muscle Relaxation Against Anxiety Levels in Elderly At Posyandu Elderly Rt 03 Rw 04 Village Tawangsari, Mojosongo Village, Surakarta. Kusuma Husada University of Surakarta

[26] Setiyowati (2019) Cognitive Restructuring for Anxiety Control in the Elderly. Proceedings of the National Seminar \& Call Paper psychology Social. Faculty Psychological Education.

[27] Qiu J, Shen B, Zhao M, et al. (2020) A nationwide survey of psychological distress among Chinese people in the COVID-19 epidemic: implications and policy recommendations. General Psychiatry 2020;33:e100213. doi:10.1136/ gpsych-2020-100213

[28] Arifiati \& Wahyuni (2019). Enhancement Sense of Humor to Reduce Anxiety in the Elderly. Indonesian Journal of Islamic Psychology Volume Number 2. Retrieved October 19,2020. From website:http://e -journal.iainsalatiga.ac.id/index.php/iji p/ index.

[29] Wang, Y., Di, Y., Ye, J., and Wei, W. (2020). Study on the public psychological states and its related factors during the outbreak of coronavirus disease 2019 (COVID-19) in some regions of China. Psychology, Health \& Medicine. two: 10.1080/13548506.2020.1746817

[30] Banerjee D. 2020. Age and ageism in COVID-19: Elderly mental health-care vulnerabilities and needs. Asian Journal of Psychiatry. vol 51:102154. doi:10.1016/j.ajp.2020.102154

[31] Yuliana,. (2020). Maintain health Mentally Elderly During the Covid Pandemic-19. Proceedings of the National Biology Seminar in the Era of the COVID-19 Pandemic. UIN Alauddin Makassar

[32] Setyaningsih (2020). Murottal Al-Mulk Therapy in Reducing Maternal Anxiety with Pre-eclampsia. Journal of Midwifery Vol 6, No 3. Malahayati University

[33] Bahrir \& Komariah (2020). Influence Murottal Al-Qur'an Therapy Against_Stress On elderly. Journal_Nursing Professional (JKP)_Volume 8, Number 1

[34] Anam,. Khasanah \& Isworo (2020). Audio Therapy with Murttal Alqur'an on the Behavior of Children ith Autism. Literature Review, Journal Of Bionursing Vol 1 (2).

[35] Yunitasari,. Sutrisno \& Suroso (2020) The Effect of Spiritual Treatment With Murottal on Anxiety, Stress, and Depression in Cervical Cancer Patients Undergoing Chemotherapy. EurAsian Journal of BioSciences Eurasia J Biosci 14, 1663-1668

[36] Syafitri (2019) Murottal Therapy Affects On Stress Aspects In The Elderly At Bpstw Yogyakarta Budi Luhur Kasongan Unit Bantul. 1st International Respati Health Conference (IRHC).

[37] Purwandani (2020). Murottal As Religious Therapy to Reduce Anxiety in the Elderly. University Muhammadiyah Malang

[38] Mohammadpoor, et all (2020) Comparison of the Effect of Instrumental Music and Holy Quran Recitation on the Anxiety of Patients with Acute Coronary Syndrome: Semi-Experimental Study. Med Surg Nurs J.;9(1):e103936. two: 10.5812/msnj.103936

[39] Rianti,. Septadina \& Prananjaya (2021). Holy Quran Recitation Of Surah AlMulk And Al-Hasyr On Decreasing Anxiety In Medical Students. International Islamic Journal Medicine.Vol, 2 No 1. https://doi.org/10.37275/ijim.v2i1.16 